REPRODUCTION

\title{
Cell phoney: human cloning after Quintavalle
}

\section{Derek Morgan, Mary Ford}

See end of article for authors' affiliations

..................

Correspondence to: Derek Morgan, Cardiff

Law School, PO Box 427, Cardiff CF10 3XJ, Wales morgandm1@cardiff.ac.uk

Received 31 March 2003 Accepted for publication 3 April 2003
J Med Ethics 2004;30:524-526. doi: 10.1136/jme.2003.004085

Reproductive cloning has thrown up new scientific possibilities, ethical conundrums, and legal challenges. An initial question, considered by the English courts in 2003, was whether the technique presently available, that of cell nucleus replacement, falls outside the provisions of the Human Fertilisation and Embryology Act 1990. If it does, the creation and use, including use in research protocols, of human embryos would be unregulated, disclosing a need to consider remedial legislation. The resolution by the courts of this legal question dramatically engages them in a resolution of fundamental ethical dilemmas, and discloses the possibilities and limitation of negotiating science policy through the processes of litigation.
$T$ he Human Fertilisation and Embryology Act 1990 contains a clear prohibition on replacing the nucleus of an embryonic cell with a nucleus taken from another human embryonic or adult cell. ${ }^{1}$ Section $3(3)(d)$ states that a licence granted under the 1990 Act "cannot authorise replacing a nucleus of a cell of an embryo with a nucleus taken from a cell of any person, embryo or subsequent development of an embryo". Cell nucleus replacement (CNR), on the other hand, is not expressly prohibited by the 1990 act; nor is "embryo splitting", the process by which twinning occurs naturally and which can also be done in vitro to produce identical, cloned embryos. The form of CNR whereby the nucleus of an oocyte is replaced with a nucleus from an adult cell was beyond the bounds of scientific credibility when the 1990 legislation was being debated and drafted.

The legal status of cell nucleus replacement has been unclear. The regulatory framework of the 1990 act rests on a definition in section 1, where an embryo is defined as "a live human embryo where fertilisation is complete" (Human Fertilisation and Embryology $\left.A c{ }^{1}{ }^{1}(\operatorname{sl}(1)(a))\right)$. This definition's emphasis on the process of fertilisation (an emphasis repeated elsewhere in sl, and throughout the act) raises the possibility that embryos created by CNR fall outwith the scope of the act, and that accordingly their creation and use is unregulated. A recent legal challenge by the campaigning organisation the Pro-Life Alliance tested the question of whether the 1990 act can be interpreted purposively to include organisms produced by CNR.

In the High Court, ${ }^{2}$ the claimant submitted simply that an embryo that has not been produced by fertilisation cannot be "an embryo where fertilisation is complete" in terms of s. 1(1)(a). The Secretary of State for Health argued for a purposive construction of section $1(1)$, whereby the sl(1)(a) definition would be expanded to include embryos produced other than by fertilisation. The judge decided that such a purposive approach would "involve an impermissible rewriting and extension of the definition" ( $R$ on the application of Quintavalle, para 62). In immediate response to this the government introduced the Human Reproductive Cloning Act 2001, under which it is an offence to place in a woman a human embryo, which has been created by any method other than fertilisation. ${ }^{3}$

In the Court of Appeal, ${ }^{4}$ the Secretary of State continued to argue that section 1 (1) must be given a "strained" construction in order to give effect to the obvious intention of parliament. The claimant disagreed that the intentions of parliament with regard to CNR could be thought to have been clear when the technique was unheard of at the time of the Act, and pointed out that, had parliament known of the CNR technique, they may well have decided to include it in the s3(3)(d) prohibition on cloning.

In upholding the appeal, the court placed particular emphasis on two considerations. First, it observed the dictum of Lord Wilberforce, in his dissenting speech in the case of Royal College of Nursing of the United Kingdom $v$ Department of Health and Social Security, ${ }^{5}$ that:

Where a new state of affairs, or a fresh set of facts bearing on policy, comes into existence, the courts have to consider whether they fall within the parliamentary intention. They may be held to do so, if they fall within the same genus of facts as those to which the expressed policy has been formulated $\left([1981],{ }^{5} 822\right.$ cited in Quintavalle $^{4} 628$ at $\left.638-9\right) .^{5}$

The court decided, regarding "genus of facts", that the fact that an embryo was created by fertilisation had not been a factor of particular relevance to the desirability of regulation when the 1990 Act was envisaged, and that, furthermore, the embryo created by CNR is "morphologically and functionally indistinguishable" (Regina, ${ }^{4}$ p 639) from the embryo created by fertilisation. The relevant point was taken to be the capacity to develop into a human being, which is shared by all embryos regardless of the method of their creation. The second point the court emphasised was the policy of the 1990 Act. Rejecting the argument that parliament's intention was undiscoverable and that CNR, if possible at the time, may have been prohibited under s3(3)(d), the court decided that the rationale behind that prohibition was

\footnotetext{
"to prevent the production artificially of two or more genetically identical individuals. This policy would be put in jeopardy if the creation and use of embryos by cell nuclear replacement were unregulated. It would be furthered by making the production of embryos by cell nuclear replacement subject to the regulatory regime under the act, for it is inconceivable that the licensing authority would permit such an embryo to be used for the purpose of reproduction (Quintavalle, ${ }^{4} \mathrm{p}$ 640).
} 
In the final appeal to the House of Lords, ${ }^{6}$ the decision of the Court of Appeal was unanimously sustained in judgments handed down in March 2003. In his speech Lord Bingham upheld the Court of Appeal's endorsement of the dictum in Royal College of Nursing, saying that this "may now be treated as authoritative" (Quintavalle, 6 para 10). Indeed, following the House of Lords' judgment in Quintavalle, the passage in question can be regarded as enshrining a new rule of statutory interpretation.

The House of Lords' decision (and the Court of Appeal ruling, which it upholds) is highly contestable, on several grounds. First, the clarity of the statutory language in sl(1)(a) casts doubt on either court's freedom to use a purposive approach to interpreting it; moreover, the 2001 Act prohibiting human reproductive cloning was in force when the appeal was considered, so the court's view that a purposive approach was necessary to prevent the production of genetically identical individuals is surprising. Second, embryos produced by the process prohibited in s3(3)(d) would also be "morphologically and functionally indistinguishable", in the words of the Court of Appeal, from embryos produced by fertilisation, just as are embryos produced by CNR, and yet parliament adopted a different regulatory approach to their creation and use. This being so, the assumption that parliament intended to treat all "morphologically and functionally indistinguishable" embryos alike seems mistaken. Finally, in its consideration of "genus", the House of Lords seems to have replicated the Court of Appeal's erroneous conflation of the term's legal application (to facts) and its scientific sense. These points are elaborated below.

The House of Lords held that CNR did not fall within the scope of s3(3)(d), which concerns the "replacement of the nucleus of a fertilised human egg", and simply left it at that. The s3(3)(d) prohibition, however, has important implications for the construction of $\operatorname{si}(1)(a)$. Precisely because s3(3)(d) is a prohibitive provision, embryos created in the manner described therein do not actually exist. Given that embryos could be created in such a way, however, it is possible to identify three theoretical categories of embryo: embryos where fertilisation is complete (E1); embryos created by CNR (E2), and embryos that might have been created in the manner otherwise prohibited by s3(3)(d), or E3.

Applying Lord Wilberforce's "genus of facts" analysis, Lord Bingham concluded that the creation of embryos by CNR belongs to the same "genus of facts" as the creation of embryos by fertilisation (Quintavalle, ${ }^{6}$ para 15(1)). He asked: "Is the embryo created by CNR different in kind or dimension from that for which the act was passed? Plainly not: as already pointed out, the organisms in question are, as organisms, very similar" (Quintavalle, ${ }^{6}$ para 15(3)).

This reasoning, however, raises several questions. First, it is not clear that the use of "genus" here accords with the legal meaning of the term "genus of facts" as applied by Lord Wilberforce; it is apparent from the speeches that the Lords are perhaps inadvertently applying a quasiscientific understanding of the term "genus". This may be excused as being a pitfall associated with the science with which the courts are asked to grapple. If, however, an error is indeed being committed, it can be traced back to the judgment in the Court of Appeal, whose application of the term to the current case was upheld in the Lords. This conflation of legal and scientific language is suggested (though not established) in the repeated references in paragraph 15 to "similar organisms".

Another question arises directly from s3(3)(d). The prohibition in that subsection also concerns what would be live human embryos- "similar organisms" to those produced both by fertilisation and by CNR. Yet their creation and use is dealt with separately and treated very differently from the creation and use of embryos produced via fertilisation. Therefore, this provision evinces parliament's intention not to treat "similar organisms" alike. Again, this reinforces the concern that the courts' approach to "genus" has been overly scientific, given that parliament clearly regarded different categories of "live human embryos" as legally and morally distinguishable despite their organic similarity.

Given the three categories of embryo that we have now identified, E1, E2, and E3, and given parliament's explicit intention to deal so differently with El and E3, we may ask, finally, why the facts surrounding E2 (CNR) embryos were regarded by the courts as being more similar to the facts of El than to those of E3. Recall that $s 3(3)(d)$ was enacted specifically to prohibit the manufacture of "genetically identical individuals" (Quintavalle, ${ }^{4}$ p 641-2). Embryological science of the 1990s has enabled the production of genetically identical organisms not by nucleus substitution but with cell nucleus replacement into an enucleated egg, so the intention behind s3(3)(d) could be said to be frustrated if that statutory language is not strained to accommodate CNR. Reading only slightly between the lines, the approach taken by the Court of Appeal and followed in the House of Lords is presented as a matter of what Ronald Dworkin has called "best fit": the "clear" will of parliament not to leave such matters unregulated (according to this rationale) requires that the Act be found to apply, and the statutory language in sl(1)(a) is more accommodating to this purpose than that in $\mathrm{s} 3(3)(\mathrm{d})$. Two responses to this are possible.

The first is one is of puzzlement: why observe the clear language of s3(3)(d) so rigidly, only to dismiss the equally clear language of $\mathrm{sl}(\mathrm{l})(\mathrm{a})$ as having only "marginal importance" (Quintavalle, ${ }^{6}$ para 14). A more cynical response might well point out that shoehorning the facts into sl(l)(a) is more expedient, politically, since it leaves the regulation of CNR up for grabs in a way that an outright ban under s3(3)(d) would not have done.

The current research purposes specified in the 1990 act relate only to research, which could be envisaged at that time. It is, however, difficult to argue that they were based on immutable moral criteria, and indeed the existence in the 1990 act of the power to broaden the research purposes in due course supports this view. Additional research purposes were, of course, added by important new regulations in 2001, as we shortly relate. In all types of embryo research under consideration it has to be accepted that the embryo cannot itself receive any benefit. It is used instrumentally-as a means to an end-and will be destroyed. This is, in any event, an inevitable outcome for all spare embryos whether donated for research under the currently allowed research purposes or no longer required for treatment. If the original arguments of the Warnock Committee are accepted the issue to be considered is one of balance-whether the research has the potential to lead to significant health benefits for others and whether the use of embryos at a very early stage of their development in such research is necessary to realise those benefits.

\section{HUMAN REPRODUCTIVE CLONING ACT 2001}

So far as CNR research within the UK is concerned the legislation now draws a line at the point of implantation by prohibiting the placing in a woman of "a human embryo, which has been created otherwise than by fertilisation". Until the Court of Appeal reversed the High Court decision, a decision now confirmed by the House of Lords, it would not have been unlawful to do CNR work preparatory to implantation. After the reversal, however, research involving CNR embryos will be lawful only where it is authorised by a licence granted by the Human Fertilisation and Embryology 
Authority (HFEA), and so long as the 2001 act remains in place it is inconceivable that the HFEA would licence research directed at human reproductive cloning.

As if these problems with the interpretation of the 1990 act were not in themselves sufficient, the Human Fertilisation and Embryology (Research Purposes) Regulations 2001, which came into force on 31st January 2001, are themselves the subject of competing interpretation. Recall that the regulations were introduced to extend the original five research purposes of the 1990 act by providing for three further purposes for which research licences may be authorised; (a) increasing knowledge about the development of embryos; (b) increasing knowledge about serious disease, or (c) enabling any such knowledge to be applied in developing treatments for serious disease.

The House of Lords select committee on stem cell research has now thrown doubt on the status and ambit of the regulations. Roger Brownsword, the legal advisor to the committee, has suggested four problems with the wording of the regulations ${ }^{7}$ :

- 1: "disease" and "serious disease"-where is the line between these concepts ("serious" having been introduced during debate); and from whose perspective is the seriousness judged; and what does "disease" mean? Does it unproblematically cover disability and disorder?

- 2: whether the regulations permit the extraction and purifying of human embryonic stem cells? Early CNR work will require the development of sound techniques for extracting and purifying human embryonic stem (HES) cells. Do the 2001 regulations clearly cover this; does itfor example, fall within new purpose (a) as being concerned with increasing knowledge? Recall that schedule 2 para 3(3) of the 1990 act provides that these additional purposes may "only" be so specified with a view to the authorisation of projects of research, which increase knowledge about the creation and development of embryos, or about disease, or enable such knowledge to be applied.

- 3: It is not clear that the regulations permit the creation of embryos. Pursuant to the new purposes it is suggested that licences to create embryos for research will be more likely to be sought than for the 181 that the chief medical officer's expert advisory group was told had been so created between 1991 and 1999. The new purposes added by the regulations do not appear to include increasing knowledge about the creation of embryos. As the House of Lords select committee on stem cell research ${ }^{8}$ resignedly observes (at 8.15); "given that the regulations explicitly recognise the development of treatments for serious disease as one of the new purposes, it would be perverse if basic research were not implicitly incorporated".

- 4: We have already observed the creation of different types or even classes of embryos; here we may distinguish additionally i) "ordinary embryos" (E1) ii) CNR embryos (E2); iii) other types of embryos (E4)-for example, those created following the inducement of eggs or stem cells induced to become embryonic, and CNR embryos generated from enucleated animal eggs or oocyte nucleus transfer; (embryos are created following an egg engineered to overcome mitochondrial defects).

The Council of Europe's Convention for the Protection of human rights, and Dignity of the Human Being, with regard to the
Application of Biology and Medicine (popularly known as the convention on human rights and biomedicine) and its additional protocol on the prohibition of cloning human beings, ${ }^{9}$ covering only reproductive human cloning, is an important document. Ten of the fifteen EU countries have now signed the convention, despite what some have seen as its (almost necessary) limitations.

The protocol makes what was implicit in the convention explicit by declaring that "[a]ny intervention seeking to create a human being genetically identical to another human being, whether living or dead, is prohibited" (Council of Europe," article 1(1)). Since "genetically identical" is defined as "sharing with another the same nuclear gene set" (Council of Europe," article l(2)), somatic cell nuclear transfer is included within this prohibition. The term "human being" is not defined in the convention, and since "human being" is unlikely to be interpreted to include embryonic human life, some countries, such as the Netherlands, in signing the convention and its protocol, have added an interpretative statement stating that

[i]n relation to article 1 of the protocol, the government of the kingdom of the Netherlands declares that it interprets the term "human beings" as referring exclusively to a human individual-that is, a human being who has been born.

The European Group on Ethics in Science and New Technologies (EGE), however, reporting directly to the president of the European Commission, advised in its opinion Ethical Aspects of Human Stem Cell Research and Use that, at present, "the creation of embryos by somatic cell nuclear transfer ['therapeutic cloning'] for research on stem cell therapy would be premature" since there are alternative sources of human stem cells. ${ }^{10}$

Taken together, these two interpretative exercises show that the debate on the legal, let alone the moral, status of embryo research is far from settled. Having negotiated the scientific, moral, and political waters, the cell nucleus replacement embryo could yet find itself adrift in the sea of legal interpretation and litigation.

\section{Authors' affiliations \\ Professor Derek Morgan, Cardiff Law School, Cardiff, Wales \\ Mary Ford, School of Law, University of Nottingham, Nottingham, UK}

\section{REFERENCES}

1 Human Fertilisation and Embryology Act 1990. London: HMSO, 1990.

2 Regina (on the application of Quintavalle) v Secretary of State for Health 2001 WL 1347031.

3 Human Reproductive Cloning Act 2001. London: The Stationery Office Ltd, 2001.

4 Regina (on the application of Quintavalle) $v$ Secretary of State for Health [2002] Q.B. 628.

5 [1981] A.C. 800 .

6 Regina (on the application of Quintavalle) $v$ Secretary of State for Health [2003] UKHL 13.

7 Brownsword R. Stem cells, Superman and the report of the select committee. (2002) 65 Modern Law Review 568.

8 HL Paper 83(i) report and (ii) evidence.

9 Council of Europe. Additional protocol to the convention for the protection of human rights and the dignity of the human being with regard to the application of biology \& medicine, on the prohibition of cloning human beings. Strasbourg: Council of Europe, 1997.

10 European Group on Ethics in Science and New Technologies (EGE). Ethical aspects of human stem cell research and use. Brussels: European Commission, 2000. 